Poznańskie Studia Teologiczne 28(2014), s. 15-31.

doi: $10.14746 /$ pst.2014.28.2

Teresa Stanek

Uniwersytet im. Adama Mickiewicza w Poznaniu

Wydział Teologiczny

\title{
Liturgical Division of the Torah as a Tool for Unit Delimitation. Preliminary Remarks
}

"Anyone comparing a number of translations and commentaries on a given passage in the Hebrew Bible soon discovers that the delimitation of clauses, verses, and larger sense units is a major source of disagreement between scholars". ${ }^{1}$ Generally, the pericope delimitation is based on literary features, ${ }^{2}$ but the high level of rhetoric sometimes renders it impossible. However, if text division is understood as part of a rhetorical strategy, used by an author who is interested in presenting his own ideas about where to pause, then divisions for liturgical readings reveal the strategies employed for presenting the sacred writings to believing communities.

Using the liturgical division of the Torah for text analysis is connected to an acceptance of the sacred nature of this canon and the need to search for hermeneutics that would recognise the active role of the believing community in creating such a text. Interpretations in agreement with Jewish traditions should point to the theological concepts and ideologies of rabbinic Judaism, but they might also be useful for any reader that wants to understand the message hidden behind reach rhetorics. If this division is logical and non-accidental, then it is worthwhile to recognise the idea behind it. This would contribute to an understanding of the Pentateuch's theological features. Another profit stemming from understanding this system might be a contribution to the delimitation of a pericope in a synchronic reading of the Bible.

This article presents five units in order to highlight the main lines that guide unit delimitation which are used for the Shabbat morning service in synagogue. Until now, I conducted research on only of six parashot ${ }^{3}$ and reviewed a few

${ }^{1}$ This is an opening remark of: Delimitation Criticism. A New Tool in Biblical Scholarship, M.C.A. Korpel, J.M. Oesch (ed.), Assen 2000. This book opened the PERICOPE series, dedicated to divisions of the text in pre-masoretic manuscripts.

${ }^{2}$ The most clear criteria are the opening clauses, change of place, or change of a character. More: Y. Amit, Reading Biblical Narratives. Literary Criticism and the Hebrew Bible, Minneapolis 2001, p. 33-45.

${ }^{3}$ T. Stanek, Jahwe i jego lud. Analiza retoryczna Wj 18,1-20,23, „Poznańskie Studia Teolo- 
others. Analysis from literary and theological points of view proved that this division is purposeful, both on the level of the parashot and the aliyot. This allows for a consideration of them as exegetical units.

\section{General outline}

Dividing biblical texts into smaller, meaningful units is witnessed in the oldest manuscripts and translations and is commonly known as the petucha and setuma. ${ }^{4}$ This system, usually called "Masoretic", is marked in all editions of the Hebrew Bible by the letters " $\mathrm{"} \mathrm{(open} \mathrm{section)} \mathrm{and} \mathrm{"} \mathrm{"} \mathrm{(closed} \mathrm{section)} \mathrm{or} \mathrm{by}$ spaces between verses, namely, at the beginning or in the middle 5 . According to the contemporary state of research, this division is logical and purposeful.

giczne" 20(2007), p. 9-19; T. Stanek, Liturgical Division of the Torah and its Interpretational Consequences. The Case of the Plague Narratives, in: M. Augustin, H.M. Niemann (ed.), Thinking Towards New Horizons. Collected Communications to the XIX ${ }^{\text {th }}$ Congress of the International Organization for the Study of the Old Testament, Ljubljana 2007, Frankfurt/Main 2008, p. 63-71; T. Stanek, Opis stworzenia świata - Rdz 1,1-6,8 - w ujęciu liturgicznej tradycji żydowskiej, in: Z. Pawłowski (red.), Genesis 1-3. Tekst, interpretacje, przemyślenia, Toruń 2009, p. 21-36; T. Stanek, Tradycyjne sposoby podziału tekstu i ich walor interpretacyjny na przyktadzie „Prawa Przymierza", in: W. Chrostowski (red.), Ex Oriente Lux. Księga Pamiqtkowa dla Księdza Profesora Antoniego Troniny w 65. rocznice urodzin, Warszawa 2010, p. 448-465; T. Stanek, Parashat Lekh Lekha (Rdz 12,1-17,27) - struktura i przesłanie, in: B. Strzałkowska (red.), Więcej szczęścia jest $w$ dawaniu aniżeli w braniu. Ksiegga pamiatkowa dla Księdza Profesora Waldemara Chrostowskiego w 60. rocznicę urodzin, Warszawa 2011, vol. 3, p. 1335-1353; T. Stanek, Gdy Izrael wychodzit $z$ Egiptu.... forthcoming.

${ }^{4}$ These divisions of the text, attested in ancient manuscripts, are now systematically treated by scholars. Their works on this subject are presented in a special series called "PERICOPE", issued by Brill. Research proved the stability of transmission not only on the level of verbalisation, but also on the level of text division. Some scholars suggest that this division can serve contemporary research as the border line of exegetical pericopes. I.e.: M.C.A. Korpel, Introduction to Pericope Series, in: M.C.A. Korpel, J.M. Oesch (ed.), Delimitation Criticism. A New Tool in Biblical Scholarship, Assen 2000 [PERICOPE 1], p. 1-50; M.C.A. Korpel, J.M. Oesch, Preface, in: M.C.A. Korpel, J.M. Oesch (ed.), Studies in Scriptural Unit Division, Assen 2000 [PERICOPE 3], p. vii; J. de Moor, Meaningful Silence. Some Remarks on the Significance of Empty Space in the Hebrew Bible, SOTS Conferences, Summer 2008, http://www.sots.ac.uk/conf/conferences2008.html [access 28.02.2012].

${ }^{5}$ This issue was systematically treated in: J.M. Oesch, Petucha und Setuma. Untersuchungen zu einer überlieferten Gliederung in hebräischen Text des Alten Testaments, Göttingen 1979. Setuma units usually contain few verses. The length of petucha units fluctuates between few lines (e.g. Ex 20:14-17; 21:11-17) to more than fifty (e.g. Gen 31:1-54). The possibility of using this system as a literary feature in Torah interpretation: C. Schedl, Geschite des Alten Testaments, Bd. I, Innsbruk 1964; D.L. Christensen, Deuteronomy. Word Biblical Commentary, t. VI a-b, Dallas 2001; T. Stanek, Tradycyjne sposoby podziału tekstu $i$ ich walor interpretacyjny na przyktadzie „Prawa Przymierza", in: Ex Oriente Lux..., op.cit., p. 450-456. 
Aside from this ancient division, there exists another system, namely, the one that is designated for the liturgical reading of the Torah in synagogue. ${ }^{6}$ Jewish tradition holds that the Torah is the life-giving text received directly from God and instituted its reading in two ways - the reading of suitable fragments during feasts, festivals, Shabbat afternoons, and week days, while during the Shabbat morning service, the reading of the Torah in a flowing manner so the whole text (without exceptions) is presented to the people. Holiness of a particular day is accentuated by the number of men called to read the Torah, amounting to seven the morning of Shabbat. ${ }^{7}$

Torah readings at Shabbat morning services historically included two major traditions. The Palestinian one that was customary in the Mediterranean Diaspora in the first millennium instituted the reading of the whole canon in a three-year cycle, but this order (customarily named, seder) ceased before the end of the $12^{\text {th }}$ century $\mathrm{AD}$. The Babylonian order instituted the reading of the whole canon within one year. Thus, the basic unit was much longer than in the Palestinian one. In time, it spread throughout other communities and finally became the only binding one that Jewish communities all over the world use to this day. ${ }^{8}$

According to the Babylonian system, the whole Torah is divided into $54 \mathrm{sec}$ tions (parashot), ${ }^{9}$ each one designated for one Shabbat. Each section (parasha) is further divided into 7 units (aliyot), which seven men read subsequently from a scroll. ${ }^{10}$ Such divisions make it that - even if the text itself keeps a flow - the listeners hear each unit as separated from the other units by a certain interval of

${ }^{6}$ General remarks: Encyclopedia Judaica; headwords: „Sedarim and Parashiyyot“; and „Sectional Divisions (Petuhot and Setumot)“. Hypothetical history of synagogue readings of the Torah: I. Elbogen, Jewish Liturgy. A Comprehensive History, Philadelphia 1993 [oryg. Der jüdische Gottesdienst in seiner geschichtlichen Entwicklung, 1913], p. 129-142.

${ }^{7}$ This is the highest number. Six men read portions of the Torah on Yom Kippur; five on the first and last day of Pilgrimage Feasts; four in remaining days of Pilgrimage Feasts and on the New Moon; three men read portions of the Torah on Chanuka, Purim, fast days, and Shabbat afternoons.

${ }^{8}$ The history and rationale of the liturgical division has not awakened much scholarly interest. Most comprehensive work on the Palestinian order: J. Mann, The Bible as Read and Preached in the Old Synagogue. A Study in the Cycles of Readings from Torah and Prophets, as well as from Psalms, and the Structure of the Midrashic Homilies, Cincinnati, Ont. 1940, vol. I-II. There are also works treating the problem from a Christian perspective collected in: Mikra. Text, Translation, Reading and Interpretation of the Hebrew Bible in Ancient Judaism and Early Christianity, M.J. Mulder, H. Sysling (ed.), Assen 1988 [CRIaNT] (contains bibliography). Until now, I have not come across any work concerning the sense of the division of the Babylonian order.

${ }^{9}$ The Book of Genesis - 12; The Book of Exodus - 11; The Book of Leviticus - 10; The Book of Numbers - 10; The Book of Deuteronomy -11 .

${ }^{10}$ In principle, each unit (aliya) should be read by a different person. Since reading a non-vocalised text from the scroll demands special skills, therefore the prevailing custom is that the text of the Torah is read by one person and the seven blessings (berakhot) are read by various people from among the congregants; the person who recited the blessing remains at the podium (bima), standing next to the reader (baal keriya). 
time. The single reading (aliya) is separated from the next by a pause of a few minutes (as one person steps down and another steps up and the $b^{e}$ rakha is recited). Each section (parasha) is separated from the others by one week. Another important feature of this division is the fact that it is addressed to people who know their religion and live by its precepts. Thus, the readings must convey a message that is important for shaping the mind of believers and encouraging them to incorporate that message into their lives.

In an exegesis of the Babylonian order (according to my knowledge), texts are only treated homiletically. Some of the $d^{e}$ rashot are based on a careful exegesis, but they only ever apply to a chosen fragment or a motif and never to the whole of the parasha. I have never encountered works that searched through the structures of those divisions or attempted to understand their rationale.

One of the most obvious signs that a certain rationale underlies this division is the length of particular sections - if the division had been made of necessity for grouping certain parts of the text together, then the length of pericopes would have been comparable. Yet, even if the difference between the parashot is not so great, it is still significant. What is more remarkable is the difference between the length of the aliyot, which vary from 6 verses (Ex 23,20-25) to more than 40 verses (e.g. Gen 30:1-43; 31:1-54). Another odd feature is the fact that those units do not often conform to the literary features at the beginning or the end of the pericope. Usually, this division does not remain in agreement with the chapter division implemented by Langton and, in many cases, it differs from the ancient (Masoretic) division of units marked by petucha and setuma. Therefore, it can be said that the Babylonian liturgical division is ruled by its own imperatives and reveals both a deep rationale and an ability to discover new meaning in comparison to the divisions made exclusively on the basis of the literary features.

\section{Examples of the Babylonian Torah Reading order division}

Now I will present the outline of structures for five parashot with the aim of demonstrating some traits of their rationale as well as an interdependence of this division and the final form of the Torah. ${ }^{11}$ Each parasha will be presented under the name by which it is called in Jewish tradition and its extent (according to Langton/Estienne division) will be marked in brackets. Further division (aliyot) of each parasha will likewise be marked in brackets and a brief comment on their specific features will be added below.

${ }^{11}$ All analysis will be done according to edition of Koren Publ., which uses the standard reading. On transmission of this division: D. Marcus, Alternate Chapter Divisions in the Pentateuch in the Light of Masoretic Sections, "Hebrew Studies" 44(2003), pp. 119-128. 
Since a more detailed analysis of these parashot has already been published, I will only highlight specific features in order to present some guidelines concerning this division. Each one of the parashot presented bears its own marks. This illustrates a variety of rhetorical approaches, which conform well to the content narrated.

\section{Parashat Bereshit - Gen 1:1-6:8}

This parasha encloses the text from the creation of the world till appearing in the figure of Noah. From a literary point of view, it joins a number of smaller narrative units as well as other genres such as hymns and genealogies.

\section{$[1: 1-2: 3]$}

The first aliya does not provoke any comments, since it is widely recognised as a unit. Its borders conform well to literary features and exegetical traditions.

\section{[2:4-2:19]}

The second aliya already displays novelty. It contains only a part of the so-called "second creation story" and covers three entities: (1) the creation of Adam, (2) planting the garden, and (3) the creation of animals. The last line speaks about submission of the animals to Adam. Such a reading makes a distinction between the creation of the world (garden/adama, adam and animals) and the creation of the humanity.

\section{[2:20-3:21]}

The third aliya (contrary to Langton's division and tradition of interpretation) joins the story about the creation of the woman and part of the narrative about "the fall" into one unit. This points to the (previously stated) difference between nature and humanity and underlines the responsibility of the latter. This reading ends at a point that does not have an ending in any other tradition, before the expulsion from the garden. The final line speaks about dressing the naked couple and so God is portrayed as a caring keeper of people in their miserable conditions.

\section{[3:22-4:18]}

The fourth aliya begins with the report of expulsion from the garden followed by the account of the births of the first and later the second son, first offering, murder, and sanctions from God. It ends with first part of Cain's genealogy (six

\footnotetext{
${ }^{12}$ T. Stanek, Opis stworzenia świata - Rdz 1,1-6,8 - w ujęciu liturgicznej tradycji żydowskiej, op.cit., p. 21-36.
} 
generations). This pericope is full of strong, negative accents. However, the ending is positive despite the condemnation of Cain's behaviour; he is still under God's protection and promised that the blessing of fertility and ruling over nature, given to humanity in creation, has not been forfeited. This aliya, both at the beginning and end, ignores the divisional and literary marks of the Masoretic system.

\section{[4:19-26]}

This very short aliya presents the end of Cain's genealogy (the repulsive figure of Lamech and his progeny) and introduces the new genealogical line of Adam and Chava. The cruelty, underlined by separating the story of Lamech, in this reading is opposed by the birth of Seth (the forefather of the post-deluge people) whose progeny turned to God the Merciful (Yahweh). This pericope contrasts not only two genealogical lines, but also two opposite cultural attitudes, i.e., material development and a religious stance.

\section{[5:1-24]}

The sixth aliya opens with a classical literary introduction (זה ספר תולדת) and has the form of a genealogy. It is limited to the third son of Adam, Seth. The key words of its beginning refer to the creation of humanity (comp. Gen 1:26-28), creating a direct link between the line of Seth and humans created directly by God. Employing standard formulas, this genealogy presents seven generations and ends with the account of Enoch's being taken to heaven.

\section{[5:25-6:8]}

The final aliya joins two motifs (literary and thematic): the remaining three generation of the genealogy of Adam through Seth and a short narrative report on the growth of iniquity among people that caused God's anguish and punishment (limitation of the length of life and deluge). The very final sentence "Noah found favour in the eyes of God" conforms to the Masoretic division (petucha) and to the literary delimitation, since the next line (the next parasha) opens using the formula of a toledot.

\section{Conclusions}

Treated as an exegetical unit, this parasha creates a kind of unity between creation and ante-deluge history, full of sinful acts, growing out of disobedience to God's admonitions or out of the presumptuousness of created beings. The most significant feature of the internal division (aliyot) is that each reading (as well as 
the whole parasha) has a positive accent at the end, in spite of the number of acts contradictory to the nature of the creation. This feature is particularly evident in the ending of the whole parasha, where the final line seems to be redundant in terms of the narrated story, but it underlines that, in spite of many misdeeds, the world and humanity are still open to the future, which depends on the obedience of persons. This division also underlines certain rhetoric within each unit, especially on the level of features such as numbers, literary plot, and motifs.

\section{Parashat Lekh Lekha - Gen 12:1-17:2713}

In terms of delimitation, this parasha, in the form of a story, is limited to a part of the Abrahamic cycle; in terms of rhetoric, it exemplifies different features. The internal divisions do not normally conform to the literary rules for the delimitation of a pericope, but they definitely throw a new light on the interpretation of the figure of Abram.

\section{[12:1-13]}

The first aliya opens at a point commonly recognised as the beginning of the Abrahamic cycle, marked also by the petucha and conforms to Langton's division, but ends at unexpected one - right after the words of Abram to Sarai on their way to Egypt. Those words underline Abram's concern about his own well-being even though he had previously received assurance from God Himself. Abram's anxiety is emphasised in a bold statement (the last line): “... that they may treat me well because of you (למעם) and spare my life out of regard (בעבור) for you". ${ }^{14}$ This ending demonstrates Abraham's temporary lack of faith in God's promise, a lack which stirs up a need to search for security in one's own way. In this way, Abram is shown to be like any human being.

\section{[12:14-13:4]}

The second aliya again ignores all the traditional means of making a pericope, not only in the beginning and ending, but also in the joining of two different plots - it describes the events in Egypt and Abram's return to Bethel. Bethel was the place where he met God for the first time in the land to which he had been sent and where he received the promise of a land. His return to this place indicates his will to repent - in Egypt, Abram experienced the power of God that had called him in Haran and now returns to the very altar at which he had con-1353 .

${ }^{13}$ T. Stanek, Parashat Lekh Lekha (Rdz 12,1-17,27) - struktura i przestanie, op.cit., p. 1335-

\footnotetext{
${ }^{14}$ These words correspond to Gen 12:2-3 in the reverse.
} 
firmed his obedience. He is now ready to resume his journey. The final line: "[...] at the place where he had formerly erected the altar [...] invoked the name of Yahweh" seems to be redundant, but underlines the closing of a certain cycle.

\section{[13:5-18]}

The third aliya starts by noticing an inability to stay with Lot, causing a departure to the area of Sodom. Right after the Lot's departure, God appeared again to Abram confirming his promise of a land. After this Abram leaves Betel and stops at Hebron, once again crossing the same way, but now he is a different person. The end of this reading is marked by a petucha and, on a literary level, closes a certain plot.

\section{[14:1-20]}

The fourth aliya begins a new story that reports conflict and war between foreign kings and the recapturing of Lot, Sodomians and their belongings by Abram and his people. The end, however, is placed at a different point - the last sentence is the blessing given to Abram by Melchizedek and Abram's giving tithes. Some mythical features present Abram as a lofty figure, elevated by his own deeds and by the priest-king.

\section{[14:21-15:6]}

This reading starts with a brief account of a discussion between Abram and the king of Sodom over the spoils. Right after boldly refusing to part of the spoil, Abram experienced a theophany in which God confirmed his promise. This time Abram answered "What use are your gifts [...] you have given me no offspring". When God assured him that the promise of multiple progeny would occur at certain time, "Abram put faith in Yahweh and this was reckoned to him as uprightness". This sentence closes the aliya. Its unique feature is its linking the two dialogs that underline the faith of the patriarch, as well as his ability to express his lack of understanding in front of God.

\section{$[15: 7-17: 6]$}

This long aliya conforms neither to Langton's text division, nor to the literary features. It covers the stories about: the first $b^{e}$ rit, appearance of Hagar and the birth of Ishmael and the opening of second $b^{e}$ rit story to the changing of Abram's name. Its ending seems uncomfortable - the elaborated promise of multiple progeny is broken in the middle with the final words: "[...] and your issue will be kings". In this way, the immediate announcement of birth of Ishmael is enveloped between the promise of the land and the promise of progeny that will rule the land. Both apply to the distant future. 
[17:7-27]

The final aliya begins with words continuing the promise and is entirely concentrated on the fundamental $b^{e}$ rit, the one that is bound with circumcision. The announcement of the birth of Isaac, the legal heir of Abraham, stays closely connected to the circumcision. By dividing chapter 17, which on the literary level forms a unit, the editor underlined and linked two important motifs - the vision of destiny of Isaac and the " $\mathrm{B}^{\mathrm{e}}$ rit Milah", which is the fundamental feature of Jewish religiosity. This story also accentuates Abraham's obedience towards the commandment received as well as its speedy execution "at the same day".

\section{Conclusions}

This parasha presents meaningful events of Abraham's story and focuses on his personal dealings. ${ }^{15}$ It begins and ends by portraying Abraham as the obedient one - he left his country without any further questioning and immediately fulfilled the prescribed circumcision. The many events described in between enabled a development within the hero's character, exposing not only his faith, but also features characteristic of each human person (e.g. hesitation in front of difficulties, limited understanding of reality, difficulty in knowing God's desires), so believers can identify with him and check their personal faith against this model. Despite the appearance of contradicting literary features, internal division underlines the growth of the character, which develops through unexpected commotions in faith and obedience.

\section{Parashat Va'era' - Ex 6:2-9:35}

The narrated story describes part of the confrontation between Yahweh and pharaoh. On the literary level it falls into two parts - introductory issues and the seven plagues which lead to the liberation of Israel from Egypt. The beginning ignores the division proposed by Langton, but conforms well to literary and thematic features. The ending accepts other divisions, in spite that it breaks the story before its solution.

\section{[6:2-13]}

The first reading presents the theme and heroes of the story. In terms of its rhetoric it is characterised by two features: repetitions of meaningful words where numerals point to the symbolic sense and many verbs that create the mood of

\footnotetext{
${ }^{15}$ The next one is much more orientated towards Abraham's dealing with the external world.

${ }^{16}$ T. Stanek, Liturgical Division of the Torah and its Interpretational Consequences. The Case of the Plague Narratives, op.cit., p. 63-71.
} 
tense and dynamics of this story. The closing sentence: “...to lead the Israelites out (להוציא) of the land of Egypt" underscores the subject of the story, repeating the leading verb: to lead out (הוציא) that first appeared as God's promise.

\section{$\left[6: 14-28^{17}\right]$}

Second aliya presents a partial genealogy characterised by the number three (three oldest sons of Jacob; three lines of Levi; three generation before Moses and Aaron). The ending goes back to the theme introduced in the previous reading, repeating twice the sentence: "...to lead the Israelites out (להוציא)". Its ending belongs to tradition (setuma), but it does not conform to Langton's division.

\section{[6:29-7:7]}

The following unit, where the proper action begins, is opened with exactly the same words as the first aliya: "God spoke to Moses saying 'I am the Lord' (אני יהוה)", and is also characterised by meaningful reiterations. The phrase "to lead Israelites out" again is repeated twice, but this act is presented as a deed of God himself (והוציאת), exactly as it was used in his opening speech (v. 6:6). A brief comment on the age of Moses and Aaron forms literary closing of this unit.

\section{$\left[7: 8-8: 6^{18}\right]$}

The fourth aliya opens with the confrontation between Yahweh - God of Israel (acting through his agent, Moses), and the pharaoh - "god" of Egypt (at the beginning acting through his agents, the magicians). This reading gives an account of the first three signs (אותות) and closes with the words: "...for the sake you know (למען תרע) that no one is as Yahweh our God". Such an ending underlines the faith confession, even if it does not conform to the Masoretic sectional division.

\section{$\left[8: 7-8: 18^{19}\right]$}

The opening verse of the fifth reading continues the narration (solution of the plague) broken by that final verse and a blessing for the new aliya. ${ }^{20}$ It has the form of a narrative. However, one can observe meaningful reiteration as well.

\footnotetext{
${ }^{17}$ In the Western exegetical tradition, this verse is connected with the following one (29) and most translations place them together as one sentence. The problem is caused by the construct state of nouns that calls for a continuation. However, verse 29 has a regular opening "Yahweh said to Moses [...]". In Masoretic accentuation, verse 28 is marked by silluq, the ending accent, however, it is lacking the atnah.

${ }^{18}$ Acc. to KJV: Ex 7:8-8:10.

${ }^{19}$ Acc. to KJV: Ex 8:11-8:22.

${ }^{20}$ This feature appears in a great number of cases that I have already investigated in the Torah.
} 
The closing sentence repeats the thematic motif from the final sentence of the previous reading: "[...] for the sake you know (למען תדע) [...]". This unit does not obey other rules of division, neither Masoretic nor literary.

\section{[8:19-9:16 $\left.{ }^{21}\right]$}

As with the preceding aliya, this one also continues the previous story, when it climaxes with the end of God's speech and execution of the announced plague. This unit is closed by a fairly long speech that Moses must deliver before pharaoh. Using a number of rare words and a lofty overtone, it announces not just one plague, but "all the plagues that Yahweh will send (שלח) into the heart of pharaoh". Its final sentence: "And I have kept you for this purpose (בעבור); for this purpose (בעבור) that you see my power; for the sake (למען) that me will be recounted (תפר) in the whole world" - not only repeats three times the phrase for the sake / for the purpose, but also, through the key words, refers to units [4] and [5]. Its goal is not just to know (ידע), but also to recount (ספר).

\section{[9:17-9:35]}

This opening of the final reading confirms the pattern observed above, where the first verse continues the previous unit and, consequently, ignores all other traditions for making a pericope. This narrative builds on the main motif used previously - division between the settlements of Israelites and Egyptians and the ending of this unit - that also closes the reading for this Shabbat - recalling the phrase "[...] for the sake you know (למען תרע)", this time with a strong explication: "that the land belongs to Yahweh". The final verse, the one summarising this unit as well as the whole section: "The heart of pharaoh was stiffened, and he did not send Israel; exactly as Yahweh predicted through Moses" gives a very concise account of the state of affairs. With this picture in mind, listeners will wait till the next Shabbat for a continuation.

\section{Conclusions}

This parasha is written in the style of a story with the brief genealogy included. Special features of it are the reiterations, which form much symbolic meaning within almost every unit. In terms of style, this section falls into two parts. For the first three aliyot, the main concern is Israel, her status, and relation to her God. The characteristic feature of it is the phrase " $[\ldots]$ to lead the Israelites out (להוציא) [...]", which is used with some variety twice in each unit. The second

\footnotetext{
${ }^{21}$ Acc. to KJV: Ex 8:23-9:16.
} 
part consists of the subsequent four aliyot built around a single theme: confrontation between Yahweh and pharaoh. Its distinct feature is the phrase: "[...] for the sake you know (למען תדע) [...]", and this warning is addressed to pharaoh. On a stylistic level, the characteristic feature is that the first line of the new aliya repeats or refers to the end of the previous reading.

\section{Parashat Bo' - Ex 10:1-13:16 22}

This unit continues the reading after a one week break. It opens with two sentences that, through the key words, relate to the ending of the previous section, but, at the same time, generate a completely different concept - while in "Va'era" it was pharaoh who was the target of knowing Yahweh (ידע), in "Bo"" it is Israel. It talks about the remaining three plagues: locust, darkness, and death of the first-born and recollects commandments referring to three issues: celebration of Passover, celebration of the Feast of Unleavened Bread, and the offering of the first born. The ending, in place of setuma, obeys the rules of literary division, but does not conform to Langton's division.

\section{[10:1-11]}

The first aliya opens with a short speech where Yahweh tells Moses that he had already hardened (הכבדתי) the heart of pharaoh and his servants (comp. v. 9:34) for the sake (למען שתי אתתי) of fulfilling all his signs (comp. v. 9:14) and also for the sake that the Israelites will recount (למען תספר) His deeds to future generations (comp. v. 9:16). The announcement of the plague of locusts opens an intense dialog with pharaoh. The dialogical form is its characteristic feature on the literary level. The conclusion, marked by the setuma, shows pharaoh in a highly negative light.

\section{[10:12-23]}

The second reading continues with the plague of locusts. It continues with its execution and solution as well as the execution of darkness. It also has a narrative form in which the ending accentuates the contrast between the fate of the Egyptians and Israelites - the former remained for three days in complete darkness, while the latter had light. The ending does not conform to either rules of division, but goes well with the concept of enunciating negative aspects in reference to pharaoh.

\footnotetext{
${ }^{22}$ T. Stanek, Gdy Izrael wychodzit z Egiptu..., op.cit., forthcoming.
} 


\section{[10:24-11:3]}

The third reading opens with pharaoh's calling to Moses and granting him permission to leave, but only under rigorous conditions. Moses' refusal received an immediate assertion from God, who had previously declared that liberation would soon come. God recommended that they borrow golden and silver ware from the Egyptians. This time the ending - describing the position of Moses - is highly positive. It is also marked by setuma.

\section{[11:4-12:20]}

The beginning of the fourth aliya expresses the typical literary marks for beginning new thoughts ("Moses then said: Yahweh says this [...]"). Its theme is the announcement of the final plague and its consequences, addressed to pharaoh, as well as instruction concerning the Passover in Egypt and the celebration of the Feast of Unleavened Bread in the Promised Land, addressed to Israel. The ending, conforming to the petucha, encloses warning against any recklessness.

\section{[12:21-28]}

The fifth aliya opens with the words: "Moses summoned all the elders of Israel and said to them [...]". Its content is limited to instruction concerning the Passover and it ends with a sentence that confirms Israel's obedience. Setuma, at this point, suggest that such partition has and old tradition.

\section{[12:29-51]}

This rather long reading has the form of a narrative. It opens with description of execution of the plague of the death of first-born (announced in fourth aliya), and then brief account of events on the leaving of Egypt. This story is logically linked to the commandments concerning the future celebration of Passover in the Promised Land. Its ending conforms both to a petucha paragraph and to Langton's division.

\section{[13:1-16]}

The final reading contains only commandments which refer to two issues: the offering of the first-born and the Feast of Unleavened Bread that must be celebrated in the Promised Land. The concluding sentences also close the reading for the adequate week and, in elaborate style, provide a justification that encourages believers to practice those commandments. Based on the key words, the final statement refers to the "Shema" prayer (comp. Dt 6:8). Langton did not end at this point, but, nevertheless, the next section (the parasha for the following week) is characterised by a different style and so the literary features suggest that this ending is adequate. 


\section{Conclusions}

In terms of literary features, this parasha is of a composite nature, since it contains narratives and nomistic texts as well as a brief genealogy. A significant number of dialogs contribute to its dynamic style despite that all action is settled within a closed area. Internal division explicates each of the important norms concerning the most vital cultic acts (celebration of Passover, celebration of the Feast of Unleavened Bread, and the offering of the first born), contextualizing and binding them to past events that justify their performance. Within this division, instruction relating to each act is read as separate. The instruction referring to celebration in Egypt is separated from those that are prescribed for the Holy Land. The ending of each aliya strengthens its message.

\section{Parashat Mishpatim - Ex 21-24 ${ }^{23}$}

This parasha that continues describing events on Sinai encloses in one unit the nomistic texts that are usually called "Covenant Code" and the narrative about covenant confirmation.

\section{[21:1-19]}

The first aliya connects four groups of norms that comprises the issues of: Hebrew slaves (1-11), conscious and unconscious killing of a man (12-14), unavoidability of the death sentence (מות יומת) in the following cases: hitting a parent, kidnapping, cursing a parent (15-17), and financial reparation for beating a man (18-19). On a literary level, the middle group demands the attention of listeners due to the laconic clauses pronouncing the three cases punished by death. Such a structure accentuates the special position of parents, whose abuse in word or deed, must be punished severely. All norms of this aliya apply to personal relations.

\section{[21:20-22:3]}

The second aliya continues the motif of punishment, but extends it towards things. It opens with the norm regarding beating a slave to death (20-21) and accidentally hitting a barren woman who miscarried (22). At the centre remains the lex talionis (23-25) and, after it, there are further norms relating to accidentally wounding a slave (26-27). Then it returns to norms relating to animals (28$-36)$ and ends with the norm relating to steeling lambs or oxen (21:37-22:3). This

${ }^{23}$ T. Stanek, Tradycyjne sposoby podzialu tekstu i ich walor interpretacyjny na przyktadzie „Prawa Przymierza”, op.cit., p. 457-465. 
pericope refers to cases serious bodily damage (sometimes leading to death), where the subject might be a human being or a domestic animal, and the responsibility incumbent on each. This one is somewhat similar to the previous one, since at the centre of this aliya are situated short clauses (in Hebrew usually 2-3 words) of lex talionis, which are surrounded by the slave motif. Norms treating injuries to animals and steeling move towards impersonal relations that are still important for communal life.

\section{[22:4-26]}

This parasha seems to be composite. It is opened by casuistic norms that refer to damaging fields (4-5), some cases of loans (6-12), including animals that could die (13-14), and the rape of a virgin (15-16). All of them are formulated in short sentences. Then there are three cases of transgressions that deserve the death sentence (omens, sodomy, and idolatry) that are formulated as apodictic laws (17-19). At the end, there are two commandments (20-26) in elaborated form, demanding justice towards the poor under threat of divine punishment. This reading contrasts the literary form. Casuistic norms apply to cases of monetary reimbursement while cases where the death sentence must be pronounced are apodictic. The phrase: "I will listen to his calling [...]" is repeated twice in the final sentences of this aliya, stressing the ethical aspect of those commandments where God himself is involved.

\section{[22:27-23:5]}

This rather short aliya (9 verses), fairly unvarying in theme and of a homiletic nature, introduces a new mood. It opens with two cultic commandments concerning tithing of the first fruits and food purity (22:28-30), which are in turn changed to those that refer to ethics in communal life: honesty (23:1), justice (23:2-3), and mercy (23:4-5). Since it is short, the interrelation between rituals and ethics must touch the addressee strongly.

\section{[23:6-19]}

The next aliya opens with commandments referring to justice (6-9), resuming the theme that closed the previous one, but then changes to address cultic issue: fallowing of the land (10-11), Shabbat rest (12), idolatry (13), pilgrimage feasts (14-17), and offerings (18-19). In comparison to previous aliya, it forms a kind of "Janus parallelism", both thematically and literarily. The three opening commandments, which listeners can link to the ending of the previous section, call for justice within the community. The cultic commandments refer to religious ritualistic behaviour and touch on the most important celebrations. 


\section{[23:20-25]}

This short aliya (only six verses long) has the form of a divine speech. This reading opens with the word: Then... (הנה), but does not have a natural ending. Since verse 26 seems to be a natural continuation, this division is postponed to the next aliya. God speaks about the near future and promises angelic assistance based on the requirements of obedience for this guiding (20-22), warning against idolatry (v. 23-24). The final verse opens with the promise of a blessing that touches three areas: bread, water, and lack of illness (25), all of which apply to personal life.

\section{[23:26-24:18]}

The final reading opens with a promise of fertility and longevity (26). This follows the sequel of blessing that ended the previous reading. It extends into further promises concerning security within the borders of their land, conquest, and the obligation of refraining from making pacts with its former citizens (27-31). Thus, they are goods that apply to communal life. This part of the promised blessing forms a good link to the following narrative that describes the confirmation of the covenant performed by Moses and the promise of stone tablets with commandments inscribed on them. From a literary point of view, the narrative chapter (Ex 24) forms a separate entity. This delimitation allows for the discovery of new features for previous commandments that in traditional exegesis are treated as a separate unit.

\section{Conclusions}

On the rhetoric level, this parasha has three parts. The first three aliyot, formed from casuistic and apodictic commandments, underlined those cases that must be severely punished, e.g., kidnapping and abuse of parents punished by death, conscious and serious bodily damage punished by analogous injures (lex talionis), and serious material harm requires adequate retribution. It is worth noting that while cases of kidnapping and abuse of parents must be punished by death, some cases of serious harm sometimes demand mercy. The second part contains two following aliyot based on commandments that deal with the land and the temple (a fundamental theme of the Torah). Each one contains both ritual and ethical decrees. The third part contains the closing two aliyot that have a narrative form, which deals with blessing and covenant. The division made in the middle of the blessing promised $(24-25 ; 26-33)$ underlines that it is conditioned by both human behaviour and God's benevolence. The first norm of this parasha refers to a Hebrew slave, calling to mind the story about enslavement in Egypt, while the ending points to the covenant and its abiding power. The varie- 
ty of commandments issued in this pericope applies both to ritual and ethics with a particular accent on covenantal obligation.

Podział Tory na czytania synagogalne jako forma delimitacji perykopy. Uwagi wstępne

\section{Streszczenie}

Podział tekstu Pięcioksięgu na mniejsze jednostki ma tradycję tak długą jak jego formowanie. Najbardziej podstawowy podział to pięć ksiąg, ale także wewnątrz niego obserwuje się podział na mniejsze jednostki. Obok starożytnego podziału, wyznaczanego przez spacje petucha i setuma, w TM zaznaczono jeszcze inny - na czytania synagogalne. W I tysiącleciu istniały dwie tradycje czytań: „cykl palestyński”, w którym cały Pięcioksiąg był czytany w cyklu trzyletnim, oraz „cykl babiloński”, dzielący Torę na 54 sekcje, uzasadnione potrzebą przeczytania jej w ciagu jednego roku. Każdy z tygodniowych odczytów dzieli się dodatkowo na siedem części.

Podział ten rządzi się własnymi prawami. Czytana perykopa pozostawia w pamięci pewne wątki, a szczególne znaczenie ma jej zakończenie. Wewnętrzny podział także odwołuje się do percepcji słuchacza, a więc również zakończenie poszczególnych części ma znaczenie dla kształtowania świadomości słuchaczy. W artykule przedstawiono pięć różnych perykop według porządku babilońskiego celem ukazania charakterystycznych rysów tego podziału.

\section{Słowa kluczowe}

Pięcioksiag, hermeneutyka, delimitacja perykopa, czytania liturgiczne

\section{Keywords}

Pentateuch, hermeneutics, pericope delimitation, liturgical readings 